\title{
Negative Gearing Redux
}

\section{George Fane and Martin Richardson}

$\mathrm{S}$ hould the interest paid by landlords on loans used to finance the purchase of rented houses and apartments be tax deductible? There is widespread agreement that interest payments should be deductible at least up to the amount of the landlord's 'net rent' - meaning the actual rent, minus all expenses other than interest payments. In this paper, we revisit Australia's controversial 'negative gearing' (NG) arrangements, under which investors can also deduct negative cash flows - defined as the excess of interest payments over earnings net of depreciation and other non-interest expenses - from their other taxable income. We focus on NG of investments in rental housing, but the principles apply also to other investments, such as equities and bonds.

Apart from a brief hiatus in 1985-87, NG has been a feature of the Australian tax system for many years. It is one of the few exceptions to Sieper's dictum that, ' $[\mathrm{t}] \mathrm{ax}$ law is as inclined to deny tax-payers full loss-offset as economists are inclined to recommend it' (Sieper, 1986:286). Indeed, it is a double exception: not only does Australian tax law allow it, but many economists and other commentators have recommended that it should be denied, on the ground that it is a tax loophole designed to steer revenues away from the Treasury. For example, Colebatch (2003) states:

Tax Office statistics show that in 1999-2000, 54 per cent of rental housing landlords claimed to be operating at a loss. They wrote off their entire rental income against tax, plus $\$ 3$ billion of losses, saving themselves tax of more than $\$ 1$ billion - which in effect, is then paid by other taxpayers.

Criticisms of NG have recently been intensified by the view that it has also contributed to an unsustainable property boom. Gittins (2003), for example, refers to 'the negative-gearing loophole on which this whole rocky edifice [the property boom] is built.'

The Reserve Bank of Australia (2003) has noted that Australia's tax treatment of rental property is out of line with that in other developed countries and has urged 'others more expert in tax matters than the Bank' to examine 'those areas where the treatment in Australia differs from that commonly seen overseas.' In fairness, it should be noted that the Bank's submission to the Productivity Commission Inquiry on First Home Ownership, from which these comments are taken, makes it very clear that they recognise the general validity of NG. Their

George Fane is Professor of Economics in the Research School of Pacific and Asian Studies and Martin Richardson is Professor of Economics in the School of Economics, The Australian National University. 
submission suggests that any changes made to eligibility for NG should also apply to assets other than rental properties, so as to preserve, 'the neutrality of the taxation system across investment classes' (Reserve Bank of Australia, 2003:55.) Former RBA Governor Bernie Fraser is less enamoured of NG, however, and has been reported as calling for its abolition.

While New Zealand, like Australia, allows full offset of interest (provided that the rent is not set 'below market rates', that is, provided that it is a legitimate rental), the UK, the US and Canada all limit the degree to which rental losses can be offset against other income for tax purposes. The UK only permits losses to be offset against future rental incomes. In the US there is an income ceiling above which such offsets are not permitted (and below which they may still be restricted). Canada requires that a 'reasonable expectation of profit' be shown, so that what is construed as a deliberate loss-making investment cannot be offset. Clearly, then, from the Reserve Bank's perspective, Australia's NG provisions should be looked at more closely.

Even political parties occasionally talk of revamping NG. The Democrats' Senator Andrew Bartlett, for example, stated in November 2003 that:

[t]here is absolutely no doubt that unrestricted access to NG for property investors and the huge cuts to capital gains tax passed by Liberal and Labor a few years ago are major contributors to the current crisis in housing affordability... The Democrats repeat our call for a proper look at all the issues that are contributing to the crisis in housing affordability, including open ended negative gearing. (Australian Democrats, 2003)

Labor's Mark Latham, on appointment as Shadow Treasurer in July 2003, stated in an evening television interview that NG was a policy that could 'easily be under review' but was contradicted the next morning by his then-leader, Simon Crean (see ABC PM (2003).) Such speedy retraction is unsurprising: as Warren (2003) notes, it is politically difficult to 'take away' something that has previously been 'given', particularly if it is capitalised into the value of property, so that its removal would cause a large loss to property owners.

Another criticism levelled at NG relates to its interaction with other deductible expenses. Kohler (2003) writes:

the real distortion with negative gearing...lies in what can be claimed as a cost against the property when calculating the loss. It's not just interest and maintenance, but also a capital allowance, or depreciation, of 2.5 per cent. That is fair enough if it's plant and machinery, but a building? Most people buy buildings in the expectation that they will rise in value not decline... That's why property is more popular than equities and bonds when it comes to negative gearing - you don't get to claim depreciation against financial assets.

Beyond confusing land values with building values, in our view this point should not be used as a criticism of NG, since the deduction to which Kohler 
refers could equally be claimed by an investor whose property was financed entirely by equity. Furthermore, whilst it is true that, 'you don't get to claim depreciation on financial assets', equities are simply claims on a firm's assets and the firm does get to claim depreciation on these (which will then show up in the value of the equity.)

On the other hand, there are many proponents of NG, particularly in the real estate and financial sectors, who use the events of 1985-87, when claimable interest expenses were limited to the value of net rental income from the property, to argue (somewhat controversially) that the abolition of NG would cause massive increases in rents.

A recent inquiry into first-home ownership in Australia by the Productivity Commission has highlighted the interaction of NG with other aspects of the Australian tax system, including capital gains tax (CGT.) The Productivity Commission (2004:121,Recommendation 5.3) recommends that a review be initiated of aspects of Australia's personal income tax regime that have led to a perceived over-investment in rental housing. They stress that the focus of that review should be on CGT provisions but that adjustments to NG might be considered as a second-best way of addressing concerns with such investment.

Our aims in this paper are twofold. First, we wish to stress and clarify the point that NG itself is entirely appropriate, in the sense that it would be a feature of an ideal income tax system. This point has been made by several commentators, most recently Evans (2004) and Quiggin (2003). However, as some of the press reports cited earlier make clear, it is still widely misunderstood. As the Productivity Commission (2004) recognises, problems can arise in the interaction between NG and various second best features of the Australian tax system. The second aim of this paper is to provide some estimates of the effective tax rates that result from these interactions, of which the most important is that between NG and the concessionary treatment of capital gains. The arguments surrounding NG stress its impact on the demand for housing (particularly rental housing) operating, presumably, through a reduction in the effective tax rate on real income derived from owning such property. Accordingly, we present simulations that attempt to estimate this effective tax rate under various assumptions about the extent of capital gains on housing and how they are taxed. In particular, we estimate the effective tax rate for four cases: with and without NG, under the current CGT regime (in which tax is paid on half of any realised nominal gain), and the regime that it replaced (in which tax was paid on the full amount of any realised real capital gain.)

\section{Negative Gearing in First and Second Best Situations}

The case for NG is that in its absence the income tax would cascade whenever investments in rental housing are financed by borrowing. To see that the consequences of denying NG would be analogous to the cascading due to a turnover tax on sales, note that, just as a cascading turnover tax can be made irrelevant by vertical integration of upstream and downstream firms, so would the 
denial of NG be made irrelevant if landlords and lenders re-arranged their portfolios to eliminate the use of debt to finance the ownership of rental housing.

To illustrate the cascading of a turnover tax, consider a wholesaler who sells a good for $\$ 100$ to a retailer who, in turn, adds $\$ 20$ of value and sells it to a consumer for $\$ 120$. If a sales tax of 10 per cent is imposed on both the wholesaler and the retailer and levied as a percentage of the net prices then the former, to still net $\$ 100$, charges $\$ 110$ of which $\$ 10$ goes to the taxman. The retailer then charges $\$ 143$, netting $\$ 130$ after tax of $\$ 13$ is extracted, to be left with $\$ 20$ still. All up, the tax raises $\$ 23$. The problem with this turnover tax is that it cascades from one stage of production to the next: the tax paid by the retailer is levied not only on their value-added but also on the already-taxed value-added of the wholesaler (and on the wholesaler's taxes as well.) This problem can be undone by vertical integration: if the wholesaler and retailer integrate then the imposition of the tax on the integrated firm's final external transaction (at $\$ 120$ ) raises $\$ 12$ and yields a final price of $\$ 132$. It can also be undone by an appropriate adjustment of the tax base to transform it into a value-added tax (VAT), in this case taxing our wholesaler $\$ 10$ (as 10 per cent of her value-added) and taxing our retailer $\$ 2$ as 10 per cent of his value-added for total tax revenue of $\$ 12$ again.

Now consider the case of a house worth $\$ 400,000$ that is entirely financed by borrowing at 10 per cent per year. Assume that the annual net rent (before deducting interest) is $\$ 25,000$ and that lender and owner both face marginal tax rates of 48.5 per cent - this is the top marginal income tax rate in Australia, resulting from combining the top scheduled rate of 47 per cent with the Medicare levy of 1.5 per cent. Absent NG, the ATO's revenue is $\$ 19,400$, or 48.5 per cent of $\$ 40,000$ (assuming that the borrower's interest payments are still deductible up to the value of the rental income, that is, $\$ 25,000$. If no deductibility of interest is allowed whatsoever then the taxman also picks up 48.5 per cent of the rental income: another $\$ 12,125$.) When NG is permitted, however, the ATO collects tax from the lender on the $\$ 40,000$ of interest received, but must allow the owner a deduction against other income of $\$ 15,000$, which is the owner's negative cash flow $(\$ 25,000-\$ 40,000)$. The ATO's net tax revenue is then $\$ 12,125$ (that is, 48.5 per cent of $\$ 25,000)$. NG effectively nets out the $\$ 40,000$ of interest payments - just as a VAT nets out upstream value-added - recognising that the net income generated by the asset (the house) does not include the servicing costs of its financing.

A cascading turnover tax can be avoided (at some cost in managerial efficiency) by re-arranging firm ownership to integrate upstream and downstream firms; similarly, the cascading effects of an income tax system that denies NG can also be undone by a simple portfolio readjustment in which the original owner sells the house to the lender for $\$ 400,000$ and uses the sale proceeds to pay off the loan. In this case, the ATO's net tax revenue would be $\$ 12,125$ once more, but it would now collect it directly by taxing the net rent of $\$ 25,000$. Under this scenario, the original loan would have been paid off and there would be no interest payments to be taxed or deducted. Tax revenue would be unchanged, but there 
would be no scope for critics to complain that landlords were getting others to pay their tax for them.

If, instead of remaining unchanged, the amount of tax collected were increased by the abolition of NG, as it presumably would be in practice, this would indicate that it is not costless for lenders and landlords to re-arrange their asset holdings to ensure that rental accommodation is wholly financed by equity, rather than being partly financed by debt.

The mistake of those who regard NG as a loophole in the tax system is their failure to notice that the sum of the correctly measured real incomes of the lender and landlord, excluding their incomes from other sources, must equal the real income generated by the only relevant asset, namely the house. Borrowing and lending do not add to the properly measured income generated by the house; they are merely ways of allowing landlords and wealth owners to specialize in the efficient sharing of the risks and hassles of providing real estate services. The waste caused by denying NG would arise because it inhibits this efficient sharing process in much the same way that the replacement of the GST by a cascading turnover tax would inhibit efficient specialization in functions among upstream and downstream firms.

There is, however, an important difference between the cascading of a turnover tax and the cascading of the income tax that would result if NG were not permitted. Since landlords would not borrow to supply rental housing at a loss unless they expected the loss to be offset by a capital gain, the negative cash flow that can be deducted from other taxable income under NG must be approximately equal to the expected capital gains on a property that is entirely financed by borrowing. If capital gains were entirely untaxed then the denial of NG - if it were not accompanied by portfolio reallocations of the sort discussed above would merely result in the collection of income tax on these capital gains. Though the critics of NG prefer to view it simply as a tax loophole, one could mount the following second-best case for its denial: even though capital gains on owneroccupied housing and equity-financed rental housing escape the net of the income tax, NG should be denied so that income tax is at least collected on the anticipated capital gains on rental housing financed by borrowing.

Since Australia's present CGT regime taxes half of nominal gains on realisation, capital gains on rental accommodation are not untaxed, but merely under-taxed. The denial of NG might therefore result in the income from rental housing being substantially overtaxed. To investigate this possibility and to estimate the extent to which the income from debt-financed rental housing is undertaxed under the present Australian tax system as a result of the lenient tax treatment of capital gains, the next section of the paper presents estimates of the effective tax rate on the real income from rental housing under various assumptions about the method of taxing capital gains, the magnitude of the real gains on rental housing, and whether NG is allowed or denied. 


\section{Quantitative Estimates of Effective Tax Rates}

For full details of these simulations see Fane and Richardson (2004). We have calculated effective tax rates on real income from rental housing in two cases, "no boom' and 'boom'. In the 'no boom' case, we make the following assumptions:

- Nominal interest rate: 8 per cent per year.

- Rate of growth of rents and house prices: 3 per cent per year.

- Rate of inflation of consumer price index (CPI): 2 per cent per year.

- Marginal tax rate of investor and lender: 48.5 per cent.

Our estimates are based on the assumption that the ratio of house prices to rents (where 'house' is a shorthand for 'house or apartment') is endogenously determined to yield zero expected pure profits (that is, after allowing for a normal rate of return to investors). This depends on the length for which the investment is held, however, so we use the simple weighted average of the pure profits for rented houses held for 5 years and 10 years. The parameter values assumed above then imply that the ratio of rents to house value is 3.0 per cent per year. While ratios of observed annual market rents to house values are generally higher than this, net rents are obviously less than market rents. The choice of 48.5 per cent for the basic income tax rate is explained above.

The interest rate and inflation rate are chosen as being fairly typical of recent Australian experience. The rate of growth of nominal rents and house prices is set at 3 per cent per year in order to give a realistic value of the ratio of net rents to house prices. The implied rate of growth of real house prices of 1 per cent per year is slightly faster than the average rate of growth of real house prices in Australia in the period 1970-96, which was 0.8 per cent per year. (Section 2.2 of the Discussion Draft of the Productivity Commission Report on First Home Ownership cites unpublished Commonwealth Treasury data according to which real house prices in Australia grew at 2.29 per cent per year, on average, over the period 1970-2003 and by 70 per cent, in total, over the period 1996-2003. These estimates imply that real house prices grew on average by 0.84 per cent per year between 1970 and 1996 and by 7.9 per cent per year between 1996 and 2003.)

Inevitably, there are many abstractions contained in this analysis and we ignore a number of options that might be embedded in an NG investor's decisions: their sale decision might be triggered by moving into a lower tax bracket (for example, at retirement), they might be able to claim as business-related expenses trips to inspect the property or expenses for minor improvements (under the guise of maintenance) and so on. Our goal is not to explain the actions of every NG investor, however, but to illustrate, in what we consider to be a fairly representative case, the interaction of NG and CGT in Australia. The important point to note is that such tax avoiding, or evading, opportunities are not directly related to NG. They are available to all owners of rental properties, regardless of the extent to which they are financed by borrowing and regardless of the extent to which the landlord's interest payments are allowed as a tax deduction. 
In recent years the rate of capital gains on housing in Australia has been far in excess of 3 per cent per year. Our estimates suggest that this is because actual capital gains on housing have far exceeded those that were expected: had the actual gains been anticipated, investment in housing would have provided a free lunch, even to those whose houses were left empty. So we also estimate the effective rate of tax on real income derived from rented housing when there is a 'boom': an unanticipated doubling of house prices. In our reported simulations, the evolution of house prices is endogenous and is determined by the stream of income generated by the house, so an unanticipated housing price boom is driven by an unanticipated increase in rentals. So to obtain these estimates, we assume that two years after making the initial investment, there is an unanticipated increase in rents of 10 per cent and the rate of increase of rents and house prices rises from 3 per cent per year to 4 per cent per year. These assumptions produce an unanticipated jump of 102 per cent in house prices two years after the initial investment, relative to what they would otherwise have been. The average growth in real prices in this case is then 9 per cent per year over 10 years, just slightly over the actual 8 per cent average real growth in Australian house prices between 1996 and 2003.

Given the assumed time paths of rents, we calculate house prices and the associated amounts of tax paid in each year under four alternative tax regimes negative gearing allowed, or denied; capital gains taxed according to the system in place in the period 1985-99, or according to the system in place since 1999. The difference between the two CCT regimes can be clarified algebraically as follows. Under the 1985-99 CGT regime, the base of the CGT in year $t$ as the result of the sale for $\$ V_{t}$ in that year of a house bought for $\$ V_{0}$ in year 0 was $\$\left(V_{t}-\alpha V_{0}\right)$, where $\alpha=\mathrm{P}_{\mathrm{t}} / \mathrm{P}_{0}$ and $\mathrm{P}_{\mathrm{t}}$ and $\mathrm{P}_{0}$ are the values of the consumer price index in the corresponding years. Under the post-1999 regime, the corresponding amount is $\$\left(\mathrm{~V}_{\mathrm{t}}-\mathrm{V}_{0}\right) / 2$.

The payments of CGT depend on the period for which the investment is held; we run separate calculations for investments held for 5, 10 and 20 years. We deflate all the annual tax payments to put them in real terms. Next we calculate the real income - defined as the real net rent plus the real capital gain generated by the house in each year. The effective tax rates are defined to be the ratios of the present values of the real tax payments to the present values of the real income. The present values can be calculated using either the net of tax real interest rate or the gross of tax real interest rate. The estimates reported below are calculated using the net of tax real interest rate.

For the reasons explained in the previous section of the paper, the income tax does not cascade if NG is allowed, and the effective tax rate is therefore independent of the gearing ratio, defined as the proportion of the purchase price of the house that the landlord finances by borrowing. However, if NG is denied, the effective tax rate depends crucially on this ratio. We report results for gearing ratios of both 40 per cent and 80 per cent. We also assume that both the landlord and the ultimate lender face the same marginal tax rate of 48.5 per cent and the same nominal interest rate. Under all tax regimes, we assume that if the landlord's 
net rent exceeds his or her interest payments on the loan used to finance the purchase of the house, then this excess is also taxable at 48.5 per cent. We assume that if NG is denied, then the landlord pays no tax and claims no deductions if the interest payment exceeds the net rent. In contrast, if NG is allowed, any excess of interest payments over net rent can be deducted from the landlord's other income, which is taxed at 48.5 per cent. The total amount of tax paid is the sum of the tax paid by the lender and the landlord, which includes any payments of CGT. The latter arise only when the house is sold.

Table 1: Effective Tax Rates on Real Income from Rental Housing ${ }^{a}$

\begin{tabular}{|c|c|c|c|c|}
\hline \multirow[t]{3}{*}{ Duration of investment: } & & 5 years & 10 years & 20 years \\
\hline & \multicolumn{4}{|c|}{ Effective tax rate on real income (per cent) } \\
\hline & \multicolumn{4}{|c|}{ Negative gearing allowed } \\
\hline \multirow[t]{2}{*}{ Post-1999 CGT regime ${ }^{b}$} & No boom $^{\mathrm{c}}$ & 52.7 & 51.3 & 48.9 \\
\hline & Boom $^{\mathrm{d}}$ & 27.8 & 28.9 & 29.2 \\
\hline \multirow[t]{3}{*}{ 1985-99 CGT regime ${ }^{\mathrm{e}}$} & No boom & 48.0 & 47.4 & 46.4 \\
\hline & Boom & 46.2 & 43.7 & 40.6 \\
\hline & \multicolumn{4}{|c|}{ Negative gearing denied (gearing ratio $=0.8$ ) } \\
\hline \multirow[t]{2}{*}{ Post-1999 CGT regime } & No boom & 64.9 & 60.2 & 53.9 \\
\hline & Boom & 38.1 & 39.2 & 38.8 \\
\hline \multirow[t]{3}{*}{ 1985-99 CGT regime } & No boom & 63.2 & 59.1 & 53.3 \\
\hline & Boom & 51.9 & 49.0 & 45.7 \\
\hline & \multicolumn{4}{|c|}{ Negative gearing denied (gearing ratio $=0.4$ ) } \\
\hline \multirow[t]{2}{*}{ Post-1999 CGT regime } & No boom & 52.7 & 51.3 & 48.9 \\
\hline & Boom & 30.1 & 31.8 & 32.4 \\
\hline \multirow[t]{2}{*}{ 1985-99 CGT regime } & No boom & 48.4 & 47.7 & 46.5 \\
\hline & Boom & 46.6 & 44.5 & 41.9 \\
\hline
\end{tabular}

Notes: a Effective tax rates are calculated as the ratio of the PV of tax paid by both lender and house owner to the PV of the pre-tax real income received, as a consequence of this transaction, by both the owner and the lender.

b Under the post-1999 regime the capital gains tax base is half of the nominal capital gain, on realisation.

c Under the 'no boom' case we assume a nominal interest rate of 8 per cent p.a., inflation of 2 per cent p.a., a marginal tax rate for both borrower and lender of 48.5 per cent and a correctly anticipated rate of growth of rents and house prices of 3 per cent p.a.

d Under the 'boom' case we suppose that 2 years after the house is purchased expectations of nominal rent growth rise (correctly) from 3 per cent to 4 per cent and there also is a discrete jump in rents of 10 per cent: these combine to generate a discrete rise in house prices of a little over 100 per cent at that point.

e Under the 1985-99 regime the capital gains tax base is all of the real capital gain, on realisation. 
The results of our simulations of effective tax rates are summarised in Table 1. Under the assumptions of the 'no boom' case, half the nominal gain on a house is less than the rate of inflation, so that the post-1999 CGT regime is in fact less generous to investors than the 1985-99 CGT regime. As a result, even when NG is allowed, the effective rate of tax on rented housing slightly exceeds the top marginal tax rate of 48.5 per cent, even for 20 -year investments. However, under the 1985-99 CGT regime, the effective tax rate is always slightly less than 48.5 per cent and is decreasing in the length of the period for which the house is held. The reason for this latter effect (under both CGT regimes) is, of course, the fact that both regimes allow investors to postpone CGT from accrual to realisation and the longer the time till realisation, the bigger the benefit from this concession.

In our view, an ideal income tax would tax real income from all sources at the same marginal rate for each taxpayer. Administrative costs being equal, this means that CGT regimes can be judged by how close their resulting effective rates of tax are to the scheduled rates of income tax. In our simulations, this means that the various CGT regimes can be judged by how close the resulting effective tax rates are to 48.5 per cent. The results in Table 1 show that, given this criterion, the 1985-99 regime is clearly superior to the post-1999 regime for the cases in which NG is allowed. There are six cases to consider: three holding periods (5 years, 10 years and 20 years), and two assumptions about the magnitude of capital gains ('no boom' and 'boom'). The only case in which the effective tax rate is not closer to the scheduled rate of 48.5 per cent under the 1985-99 regime than under the post-1999 regime is in the 'no boom' 20-year case, when the current regime 'overtaxes' by 0.4 percentage points and the previous regime 'undertaxes' by 2.4 percentage points.

As noted above, we derive two sets of estimates for the case in which NG is denied, which differ only in the percentage of the house value that is assumed to be loan-financed. Both sets assume that investors know in advance whether NG is allowed or denied. As in the case in which NG is allowed, the effective rate of tax on real income is always higher in the 'no boom' case, for each maturity, under the post-1999 regime than under the 1985-99 regime and, for each regime, the rate is always lower on longer maturity investments than on shorter maturity ones. Reducing the proportion of gearing on the house reduces the effective tax rate when NG is denied in all cases but, under the current CGT regime, it always remains above the scheduled rate of 48.5 per cent for all holding periods we consider.

The effective tax rates for the cases in which NG is denied then range from 54 to 65 per cent, when 80 per cent of the house value is loan-financed (and 49 to 53 per cent when only 40 per cent is loan-financed) the exact number depending on the duration of the investment and the CGT regime in place. Part of the reason for this over-taxation is that capital gains on rental housing are already taxed to some extent under both the present Australian tax system and under the system that was in place between 1985 and 1999. Another part of the reason is that the losses deductible under NG include the inflation component of nominal interest payments. Since lenders pay tax on their nominal interest receipts, it is 
appropriate that borrowers should be able to deduct nominal interest payments. The faster the rate of inflation, the larger would be the cascading effect of denying NG.

The assumptions underlying our estimates are inevitably arbitrary; different assumptions about the timing of the unanticipated doubling in house prices and about the proportions in which it is due to increases in the level of rents and their expected rate of growth would produce different estimated effective tax rates. However, we are confident that our 'boom' case gives the right order of magnitude for the effective tax rates that would result from an unanticipated doubling in house prices. These rates are nearly all less than the scheduled rate of 48.5 per cent that is assumed to apply to interest receipts. The reason that this is true even for most cases when NG is denied is that capital gains, which receive favourable tax treatment compared to other sources of income, are so large in this scenario that they dwarf all other sources of income. In this 'boom' case, the nominal gains are so large, relative to the underlying rate of CPI inflation, that the difference between real and nominal gains is minor. Under the 1985-99 regime the favourable treatment of real capital gains results only from the deferral of taxation of gains, but under the post-1999 regime, there is the additional effect that tax is levied on only half of nominal gains.

\section{Conclusion}

At the beginning of our discussion of NG in first- and second-best situations we showed that NG is not a loophole in the tax system, but rather something that would be allowed in any system that taxed real income, properly measured. The main weakness of the Australian income tax is the taxation of capital gains, which is a major loophole when gains are rapid, but errs in the opposite direction when asset prices grow at less than twice the rate of growth of the CPI.

With respect to CGT, our estimates of the effective rates of income tax show that, judged by the criterion of how closely each regime approximates an ideal tax on real income, the 1985-99 regime is clearly superior to the present regime under a wide range of alternative assumptions. Since the administrative costs of the 1985-99 and post-1999 CGT regimes are the same, there is no justification for the adoption of the economically inferior one. Compare our earlier formulae for the two regimes. The only extra information needed to estimate tax liabilities under the former system is the consumer price index. The cost to the ATO of making this index available to taxpayers is obviously negligible.

We considered above a second-best argument that, because of the concessionary tax treatment of capital gains when asset prices are rising rapidly, NG should be denied so as to collect tax on the anticipated capital gains on rental housing financed by borrowing. This second best case for denying NG has three weaknesses. First, the denial of NG would not remove the incentives to overinvest in rapidly appreciating assets, because it would not affect the taxation of such assets if they were financed out of equity. Second, by taxing investments financed by debt more heavily than those financed by equity, it would distort 
portfolio choices and create a bias against financial intermediation. Third, it would exacerbate the existing bias in favour of owner-occupancy and against renting created by the non-taxation of housing services accruing to owneroccupiers.

In the last section of the paper we showed that the denial of NG would result in very substantial over-taxation of the income from debt-financed rental housing under plausible assumptions about the anticipated capital gains on housing. We then discussed the results for the case in which, in addition to anticipated slow real capital gains, there is also an unanticipated doubling of house prices. In this case, even the denial of NG is not sufficient to keep the effective tax rate on real income from debt-financed rental housing near the top marginal rate of 48.5 per cent, under the current CGT regime. The reason is that if there is a very large boom in house prices, almost all the real income from rental housing accrues in the form of capital gains and these are grossly under-taxed by the present CGT regime, and would have been significantly under-taxed by the previous CGT regime, which did not tax real gains until they were realised.

Even if over-taxing anticipated gains on rental housing is less inefficient than under-taxing them, it would be better still, for the reasons discussed above, to attack the basic problem directly by making the CGT as efficient as possible, rather than by trying to deal with its inadequacies by denying deductions elsewhere in the system that would be allowed under an ideal income tax.

\section{References}

ABC PM (2003), 'Costello Attacks Latham on Negative Gearing Statements', Transcript 3 July, 2003, http://www.abc.net.au/pm/content/2003/s894364.htm.

Australian Democrats (2003), 'Reserve Bank Makes it Clear — Investment Housing Taxes Need Review', Press Release 03/822, 15 November 2003, http://www.democrats.org.au/news/index.htm?press_id=3130.

Colebatch, T. (2003), 'Why Costello Should Scrap Negative Gearing', The Age, 8 July 2003, http://www.theage.com.au/articles/2003/07/07/10574301356 58.html.

Evans, T. (2004), 'Economic Theory and Policy: Some Thoughts', Economic Papers 23(1):39-43.

Fane, G, and M. Richardson (2004), 'Capital Gains, Negative Gearing and Effective Tax Rates on Income from Rented Houses in Australia', Working Paper in Trade and Development No.2004/05, The Australian National University.

Gittins, R. (2003), 'This Is the Way the Big Boom Ends', Sydney Morning Herald, 2 July 2003, http://www.smh.com.au/articles/2003/07/01/1056825394151 .html.

Kohler, A. (2003), 'Forever Blowing Bubbles', Weekend Australian Financial Review, 1213 July 2003:10. 
Productivity Commission (2003), First Home Ownership, Draft Report, Melbourne, http://www.pc.gov.au/inquiry/ housing/draftreport/housing.pdf.

Productivity Commission, 2004, First Home Ownership, Report No. 28, Melbourne, http://www.pc.gov.au/inquiry/housing/finalreport/housing.pdf.

Quiggin, J. (2003), 'In Defence of Negative Gearing', http://mentalspace.ranters.net/quiggin/archives/001107.html.

Reserve Bank of Australia (2003), 'Submission to Productivity Commission Inquiry On First Home Ownership', http://www.pc.gov.au/inquiry/housing/subs/sublist.html (Submission No. 199).

Samuelson, P. (1964), 'Tax Deductibility of Economic Depreciation to Ensure Invariant Valuations', Journal of Political Economy 72:604-606.

Sieper, E. (1986), 'Business Tax Reform', pp. 279-314 in J. Head (ed.) Changing the Tax Mix, Australian Tax Research Foundation, Sydney.

Warren, N. (2003), 'No Easy Way to Unwind Negative Gearing', Australian Financial Review, Thursday 10 July 2003:63.

We are very grateful to Matt Benge for extensive comments on an earlier draft. We also thank the editor and two anonymous referees for their helpful comments and suggestions. All remaining errors are, of course, our own. 